\title{
Concurrent infections of dengue virus serotypes in Bali, Indonesia
}

\author{
Sri Masyeni ${ }^{*}$ (D), Benediktus Yohan ${ }^{2}$ and R. Tedjo Sasmono²
}

\begin{abstract}
Objective: To describe cases of dengue virus (DENV) concurrent infections in patients from both local and international traveler visiting Bali, Indonesia.

Results: During a hospital-based study, 260 patients (from 161 local and 99 international traveler patients) were recruited. Among them, 190 were positive by DENV RT-PCR in which eight patients (five local and three international travelers) detected as having concurrent infections by two different DENV serotypes. Among the eight patients, the common dengue symptoms diagnosed were fever, headache, and myalgia. Six cases (75\%) were diagnosed with dengue fever (DF) while two cases (25\%) manifested with bleeding and were diagnosed with dengue hemorrhagic fever (DHF) grade 1. The DENVs concurrent infections involved all four DENV serotypes known to be circulating in Bali. Although cases of DENV concurrent infections have been implicated with severe manifestation, we observed that most of concurrent infections cases in our study were of mild clinical manifestation, that may be related to the changing of DENV serotype predominance which is occurring in Bali, Indonesia.
\end{abstract}

Keywords: Dengue, Concurrent infections, Serotype, Bali, Traveler

\section{Introduction}

The dengue disease, caused by the etiological agent dengue virus (DENV) has been considered as the most important arboviral infection in the world, with significant burden [1]. All four serotypes of DENV (DENV-1, $-2,-3$, and -4 ), members of the Flaviviridae family, may induce long-lived serotype-specific immunity and only confers short-lived cross-immunity [2]. Clinical manifestations of DENV infection vary from asymptomatic, mild dengue fever (DF), to the more severe dengue hemorrhagic fever (DHF) and life-threatening dengue shock syndrome (DSS), for particular people [3-5]. Risk factors for severe dengue are young age, female sex, high bodymass index, virus strain, and genetic variants [6-8].

All four DENV serotypes were found to circulate in Asia, Africa and America with co-circulation of multiple DENV serotypes reported [9]. Co-circulation of DENV serotypes increases the risk of concurrent infections, a

\footnotetext{
*Correspondence: masyeniputu@yahoo.com

${ }^{1}$ Faculty of Medicine and Health Sciences, Warmadewa University, J. Terompong No. 24, Denpasar, Bali 80235, Indonesia

Full list of author information is available at the end of the article
}

phenomenon best observed in epidemics $[10,11]$. It has been reported that the occurrence of concurrent infections was ranging from $5 \%$ to as high as 50\% [11].

Conflicting outcomes were reported in which concurrent infections of DENV serotypes may lead to mild or severe dengue manifestation [11-15]. The concurrent infections of DENV-serotypes in Indonesia has been reported, including in Bali [16] which has been known as a famous tourist destination both local and international. The hyperendemicity of DENV in Bali may affect both local people and international travelers [17].

In this report, we present cases of DENV concurrent infections in local Balinese and international travelers admitted to tertiary hospitals in Bali. The clinical manifestation characteristics related to cases of DENV concurrent infections were sought and assessed together with molecular surveillance data.

\section{Main text \\ Methods}

Sample collection and processing

This study was part of dengue and other viral diseases molecular surveillance study in local and international 
travelers visiting Bali, commenced in 2015-2017 [16, 17]. Samples were collected from patients seeking medication to three tertiary hospitals in Bali, namely RS Kasih Ibu, Denpasar; RS Sanjiwani, Gianyar; and RS Wangaya, Denpasar. Serum samples were obtained from patients' blood during acute phase from day 0 up to day 5 of fever onset and convalescence sera were taken on patients' hospital discharge day. All patients were adults with age of $>14$ years old. The grading of dengue clinical manifestation was implementing the WHO-SEARO guidelines [8] and diagnosis of dengue hemorrhagic fever (DHF) was based on the evidence of plasma leakage which includes the hematocrit (HCT) level increase or the findings of pleural effusion or ascites on physical examination. The assessment of plasma leakage evidence was performed based on $>20 \%$ drop in HCT following volume replacement treatment compared to baseline [8], i.e. HCT level differences of more than $20 \%$ between the highest HCT level recorded during the phase of illness and level during convalescence. Thrombocytopenia was defined as a rapid decline of platelet with platelet count of $<100 \times 10^{9} / \mathrm{L}$.

\section{Serology testing, DENV detection, serotyping, and genotyping}

The anti-DENV IgM and IgG serology detection was done using Panbio Dengue Duo IgM/IgG ELISA kit (Alere, Brisbane, Australia) to determine the infection status as primary or secondary infection, as described previously [18]. Dengue was confirmed through DENV NS1 antigen detection using the SD Bioline NS1 Rapid Test (Alere). The DENV RNA was extracted from serum sample using QIAamp Viral RNA Mini kit (Qiagen, Hilden, Germany) according to the manufacturer's instructions, and used as template in simultaneous DENV detection and serotyping by real-time RT-PCR using Simplexa Dengue (DiaSorin, Cypress, CA, USA), as described elsewhere [19]. The positively detected DENV nucleic acid in samples was reported as the resulting DENV serotype and its $\mathrm{Ct}$ value correspond to the semi-quantitative measurement of viral titer where lower $\mathrm{Ct}$ value correlate with higher viral titer and vice versa. Genotype determination was performed using Sanger capillary sequencing of the DENV envelope (E) gene, as described elsewhere [20].

\section{Results}

\section{Clinical and laboratory examinations of the concurrent infections cases}

A total of 260 samples were collected during the study. The total samples comprise of 161 local and 99 international traveler patients. Among them, eight patients were of DENV concurrent infections as simultaneously detected and serotyped using real-time RT-PCR. The clinical and laboratory examinations data of patients with DENV concurrent infections were summarized in Table 1.

All cases presented with fever and the majority of patients had headache, myalgia, and vomiting. There was no serious bleeding observed in cases, except for petechiae and gum bleeding. Likewise, there was no fluid accumulation or shock observed in all cases. The level of liver enzymes and albumin were gradually reached the relatively normal level. Laboratory results showed no signs of leukocytosis in majority of the cases with relatively normal hemoglobin levels. Thrombocytopenia was observed only in case $2,3,4$, and 6 .

\section{DENV infection status, serotypes, and genotypes}

In term of DENV infection status as inferred from serology results, most of the cases were of secondary infection. We observed that secondary infection was observed in all local patients, while all international travelers were characterized as of primary infection (Table 1). Serology detection revealed the IgM positivity of $87.5 \%$ among concurrent infections cases.

From 260 collected samples, 190 were successfully determined for their infecting DENV serotype. Among them, 182 samples were of mono-infection while 8 samples were of concurrent infections of two different DENV serotypes. The DENV concurrent infections involved all four DENV serotypes with most of the cases involving DENV-1 (Table 1). Three cases were of DENV-1 and -2 concurrent infections while two cases involving DENV-1 and -3 . The remaining two cases involved DENV-2 and -4 and one case serotyped as having DENV-3 and -4 . In term of the $\mathrm{Ct}$ values of each DENV serotype measured using real-time RT-PCR, majority of cases showed relatively equal $\mathrm{Ct}$ values although there was presence of higher $\mathrm{Ct}$ value in one serotype than the other serotype of the concurrent infections (Table 1).

Genotype determination was performed to one case of concurrent infections (Case 8) where both of the DENV-2 and -4 serotypes were successfully sequenced (data not shown). Utilizing Twiddy, et al. classification for DENV-2 [21], the DENV-2 isolate of case 8 was grouped into the Cosmopolitan genotype. The other DENV-4 isolate of case 8 was classified into the Genotype II of DENV-4 grouping based on Lanciotti, et al. classification [22].

\section{Data comparison between DENV mono-infection and concurrent infections cases}

We performed a comparison between clinical and laboratory data from cases with mono-infection and concurrent infections (Table 2). However, the small number of concurrent infections cases was limiting statistical analysis. 
Table 1 Demographic and clinical variables among concurrent infections cases

\begin{tabular}{|c|c|c|c|c|c|c|c|c|}
\hline Variable & Case 1 & Case 2 & Case 3 & Case 4 & Case 5 & Case 6 & Case 7 & Case 8 \\
\hline \multicolumn{9}{|c|}{ Demography and clinical manifestations } \\
\hline Age range, years old & $20-30$ & $20-30$ & $30-40$ & $40-50$ & $30-40$ & $40-50$ & $50-60$ & $50-60$ \\
\hline Race/nationality & Balinese & Balinese & Balinese & Balinese & Balinese & French & French & Austrian \\
\hline Gender & Male & Female & Male & Male & Male & Female & Male & Male \\
\hline Fever day & 3 & 3 & 3 & 5 & 2 & 3 & 3 & 3 \\
\hline Headache & + & + & + & - & - & + & + & + \\
\hline Arthralgia & + & + & + & + & - & + & - & + \\
\hline Myalgia & + & + & + & + & - & + & - & + \\
\hline Vomiting & + & + & - & - & - & + & - & - \\
\hline $\begin{array}{l}\text { Bleeding manifesta- } \\
\text { tion }\end{array}$ & + (Petechiae) & - & - & - & - & $+($ Gum $)$ & - & - \\
\hline Shock & - & - & - & - & - & - & - & - \\
\hline Plasma leakage & - & + & - & + & - & - & - & - \\
\hline Comorbidity & - & - & - & - & - & - & $+(\mathrm{DV} T)$ & - \\
\hline \multicolumn{9}{|c|}{ Laboratory examinations data } \\
\hline $\begin{array}{l}\text { Nadir WBC }(\times 10 \mu \mathrm{g} / \\
\mu \mathrm{L})\end{array}$ & 4.10 & 3.00 & 2.70 & 2.90 & 2.06 & 1.16 & 2.84 & 1.13 \\
\hline HCT difference (\%) & 12.0 & 21.4 & 9.9 & 21 & 11.9 & 6.1 & 7.4 & 11.1 \\
\hline Nadir PLT $\left(\times 10^{9} / \mathrm{L}\right)$ & 122 & 91 & 16 & 56 & 114 & 56 & 117 & 113 \\
\hline $\operatorname{AST}(U / L)$ & 34 & 167 & $\mathrm{~N} / \mathrm{A}$ & 164 & $\mathrm{~N} / \mathrm{A}$ & 24 & 59 & 40 \\
\hline $\operatorname{ALT}(U / L)$ & 23 & 190 & $\mathrm{~N} / \mathrm{A}$ & 168 & $\mathrm{~N} / \mathrm{A}$ & 14 & 42 & 36 \\
\hline Albumin (g/L) & 3.8 & 3.0 & $\mathrm{~N} / \mathrm{A}$ & 3.4 & $\mathrm{~N} / \mathrm{A}$ & N/A & 3.8 & 3.8 \\
\hline DENV NS1 & + & + & + & + & + & + & + & + \\
\hline Dengue IgM & + & + & - & + & + & + & + & + \\
\hline Dengue IgG & + & + & + & + & + & - & - & - \\
\hline Infection status & Secondary & Secondary & Secondary & Secondary & Secondary & Primary & Primary & Primary \\
\hline Severity & DF & DHF grade 1 & $\mathrm{DF}$ & DHF grade 1 & DF & $\mathrm{DF}$ & $\mathrm{DF}$ & DF \\
\hline $\begin{array}{l}\text { DENV Serotype (RT- } \\
\text { PCR Ct value) }{ }^{\mathrm{a}}\end{array}$ & $\begin{array}{l}\text { DENV-2 (19.8), } \\
\text { DENV-4 } \\
(38.7)\end{array}$ & $\begin{array}{l}\text { DENV-1 (16.0), } \\
\text { DENV-2 } \\
(35.1)\end{array}$ & $\begin{array}{l}\text { DENV-1 (16.3), } \\
\text { DENV-3 } \\
(29.2)\end{array}$ & $\begin{array}{l}\text { DENV-1 (33.3), } \\
\text { DENV-3 } \\
(31.9)\end{array}$ & $\begin{array}{l}\text { DENV-3 (29.0), } \\
\text { DENV-4 } \\
(38.5)\end{array}$ & $\begin{array}{l}\text { DENV-1 (29.1), } \\
\text { DENV-2 } \\
(29.1)\end{array}$ & $\begin{array}{l}\text { DENV-1 (25.2), } \\
\text { DENV-2 } \\
(20.6)\end{array}$ & $\begin{array}{l}\text { DENV-2 (24.5), } \\
\text { DENV-4 } \\
(22.7)\end{array}$ \\
\hline
\end{tabular}

+, positive; -, negative; DF, dengue fever; DHF, dengue hemorrhagic fever; WBC, white blood cell; HCT, hematocrit; PLT, platelet; AST, aspartate aminotransaminase; ALT, alanine transaminase; DVT, deep vein thrombosis; N/A, not applicable due to insufficient sample volume

a Determined using Simplexa Dengue qRT-PCR

Despite the gender proportion, other clinical and laboratory experiment data showed similar features, including the infection status where the majority of mono-infection and concurrent infection cases were of secondary infection. In term of severity, concurrent infection cases showed relatively milder manifestations than cases of mono-infection.

\section{Discussion}

The circulation of multiple DENV serotypes within the same geographical area increases the risk of concurrent infections that mostly occurs during an epidemic [10, 11]. The first case of DENV concurrent infections was reported from a study in Puerto Rico in 1982 [14]. Historically, DENV concurrent infections cases has been reported in samples isolated in Indonesia since 1976 [15].
The recent surveillance reports from Indonesia reported the DENV concurrent infections occurrence ranged from 1.6 to $29.0 \%[16,18,20,23,24]$.

It has been proposed that DENV hyper-endemicity, which leads to concurrent infections, was the contributing factor for severe dengue [12]. However, in this case report, the occurrence of DENV concurrent infections in patients was related to relatively mild clinical manifestation with no serious bleeding, fluid accumulation or shock observed (Table 1). The clinical assessment results were supported with laboratory examination data in which no signs of leukocytosis, one of the indicators of severe dengue [25], was detected. However, signs of thrombocytopenia were observed in some of the patients (Table 1). Two cases were clinically graded as DHF grade 
Table 2 Demography, clinical, and laboratory data comparison between mono-infection and concurrent infections cases during dengue surveillance in Bali

\begin{tabular}{|c|c|c|}
\hline Variable & $\begin{array}{l}\text { Mono-infection } \\
\text { cases }(\mathrm{N}=182)\end{array}$ & $\begin{array}{l}\text { Concurrent } \\
\text { infections cases } \\
(\mathrm{N}=8)\end{array}$ \\
\hline \multicolumn{3}{|c|}{ Demography and clinical manifestations } \\
\hline Age, median year (range) & $28(14-75)$ & $42(25-53)$ \\
\hline Male, N (\%) & $80(44.0)$ & $7(87.5)$ \\
\hline Female, N (\%) & $102(56.0)$ & $1(12.5)$ \\
\hline Fever day, days $\pm S D$ & $3.3 \pm 0.83$ & $2.0 \pm 0.93$ \\
\hline Headache & $139(76.4)$ & $7(87.5)$ \\
\hline Arthralgia & $101(55.5)$ & $6(75.0)$ \\
\hline Myalgia & $122(67.0)$ & $6(75.0)$ \\
\hline Vomiting & $92(50.5)$ & $2(25.0$ \\
\hline Bleeding & $46(25.3)$ & $2(25.0)$ \\
\hline Plasma leakage & $0(0.0)$ & $0(0.0)$ \\
\hline Shock & $0(0.0)$ & $0(0.0)$ \\
\hline \multicolumn{3}{|l|}{ Laboratory examinations data } \\
\hline $\begin{array}{l}\text { Nadir WBC }(\times 10 \mu \mathrm{g} / \mu \mathrm{L}) \text {, median } \\
\text { (range) }\end{array}$ & $2.1(0.48-6.4)$ & $2.77(1.16-4.1)$ \\
\hline $\begin{array}{l}\text { HCT difference (\%), median } \\
\text { (range) }\end{array}$ & $13.1(2.43-68.9)$ & $11.5(6.1-21.4)$ \\
\hline $\begin{array}{l}\text { Nadir PLT }\left(\times 10^{9} / L\right) \text {, median } \\
\text { (range) }\end{array}$ & $43(6-194)$ & $102(16-122)$ \\
\hline DENV NS1 test positivity, N (\%) & $173(95.1)$ & $8(100.0)$ \\
\hline Dengue IgM positivity, N (\%) & $123(67.6)$ & $7(87.5)$ \\
\hline Dengue IgG positivity, N (\%) & $142(78.0)$ & $5(62.5)$ \\
\hline \multicolumn{3}{|l|}{ Dengue severity } \\
\hline$D F, N(\%)$ & $110(60.4)$ & $6(75.0)$ \\
\hline DHF grade 1, N (\%) & $42(23.1)$ & $2(25.0)$ \\
\hline DHF grade 2, N (\%) & $26(14.3)$ & $0(0.0)$ \\
\hline DHF grade 3, N (\%) & $4(2.2)$ & $0(0.0)$ \\
\hline DHF grade 4, N (\%) & $0(0.0)$ & $0(0.0)$ \\
\hline
\end{tabular}

DF, dengue fever; DHF, dengue hemorrhagic fever; WBC, white blood cell; HCT, hematocrit; PLT, platelet

I due to the HCT levels difference of more than $20 \%$ between acute and convalescence sera (Table 1).

The majority of concurrent infections cases were of secondary infection as determined by serology and all of them are patients from local Balinese. It has been reported that the number of secondary infection in adults are higher, especially in an endemic area like Bali with prolonged exposure to dengue infection in the past [16]. Interestingly, cases from international travelers were of primary infection with only anti-DENV IgM antibody detected (Table 1). Looking into their history, the travelers stated that they have never been contracted to dengue in the past. Moreover, the travelers were coming from countries where dengue is not endemic.
The DENV serotypes involved in concurrent infections were mostly involved DENV-1 and dominated by mix of DENV-1 and -2, followed by DENV-1 and -3, DENV-2 and -4, and DENV-3 and -4. In term of clinical manifestation caused by DENV concurrent infections, our findings are in line with previous reports from Brazil which observed mild dengue manifestation caused by concurrent infections of DENV-1 and DENV-2 [26, 27] and DENV-3 and DENV-4 [28]. The involvement of DENV-1 in majority of the concurrent infections cases was also observed in previous reports of concurrent infections in Semarang [20] and Surabaya [18]. Reports have been proposing the phenomena of serotype replacement in places in Indonesia where DENV-1 has becoming the predominant serotype [18, $20,23,24,29]$. Our previous dengue surveillance in local Balinese observed the rise of DENV-1 infection as the second most common serotype detected in patients [16]. It may happen that this cyclical serotype predominance is currently occurring in Bali, the condition that needs to be continuously monitored. The relationship of DENV-1 predominance with mild dengue manifestation has also been observed in a surveillance study in Jambi, Sumatra [23].

Previous studies have correlated the higher viremia level with severe dengue clinical manifestation in DENV concurrent infections [12, 30]. In a case report, significantly higher titer of DENV-3 over DENV-2 was recorded in which may suggest the better replication rate of the former compared to the latter [12]. However, in this study, only one DHF case was reported to have significantly higher viral titer (as of Ct value) of DENV-1 over DENV-2. In other DHF case, similar Ct values were recorded. Moreover, we did not observe the correlation of higher DENV serotype titer with severe clinical manifestation in the majority of cases (Table 1). It has also been reported that the host (secondary infection status) and viral factors (viral load titer) influenced the clinical phenotype of severe dengue manifestations [31]. Our data may suggest that there may be other factors influencing clinical manifestation, especially in concurrent infections cases.

Looking deeper into the genotypes of the DENV serotypes from the concurrent infections cases, both genotypes of the infecting DENV serotypes were successfully obtained for one case. The DENV-2 isolate of case 8 were grouped into Cosmopolitan genotype and the DENV-4 classified as Genotype II. These classifications were still correspond to the genotype data of DENV in Bali [16], reflecting the endemicity of DENV and occurrence of active virus transmission in the island.

In term of comparison between concurrent infection samples and other samples detected as having only single 
or mono infection, we observed a relatively similar clinical and laboratory profiles where relatively milder manifestations were observed in concurrent infections cases (Table 2). Nevertheless, both groups reflected mild dengue manifestations where the majority of them were of DF manifestation, with only a small proportion developing DHF $[16,17]$. Although it has been reported that coinfected patients are skewed towards more severe clinical manifestations compared to mono-infected patients [11], in this research note, our results suggested that patients having concurrent infections of DENV were not prone to severe disease.

In conclusions, we report cases of DENV concurrent infections among local Balinese and international travelers. We highlighted that the concurrent infections were not directly associated with severe dengue.

\section{Limitations}

The small number of concurrent infections samples described may not be sufficient to describe the clinical manifestation related to DENV concurrent infections. Hence, this finding needs to be supported with bigger and nation-wide surveillance data.

\begin{abstract}
Abbreviations
DENV: dengue virus; DF: dengue fever; DHF: dengue hemorrhagic fever; DSS: dengue shock syndrome; RT-PCR: reverse transcriptase polymerase chain reaction; NS1: non-structural protein 1; RNA: ribonucleic acid; HCT: hematocrit; IgM: immunoglobulin M; IgG: immunoglobulin G; PLT: platelet; AST: aspartate aminotransaminase; ALT: alanine transaminase; DVT: deep vein thrombosis.
\end{abstract}

\section{Authors' contributions}

SM analyzed and interpreted patient clinical data and performed literature review. SM and BY performed the experiments and analyzed the data. SM, BY, and RTS wrote the manuscript. RTS also contributed to the generation of the final manuscript and general supervision. All authors read and approved the final manuscript.

\section{Author details}

${ }^{1}$ Faculty of Medicine and Health Sciences, Warmadewa University, Jl. Terompong No. 24, Denpasar, Bali 80235, Indonesia. ${ }^{2}$ Eijkman Institute for Molecular Biology, Ministry of Research, Technology, and Higher Education of the Republic of Indonesia, J. Diponegoro 69, Jakarta 10430, Indonesia.

\section{Acknowledgements}

The authors thank the patients who participated in this study. Technical assistance from Ms. Marsha S. Santoso in data compilation is greatly appreciated.

\section{Competing interests}

The authors declare that they have no competing interests.

\section{Consent for publication}

Not applicable.

\section{Ethics approval and consent to participate}

The ethical considerations of the study were approved by the Medical Research Ethic Committee of Udayana University/Sanglah General Hospital, Bali with approval no. 122/UN.14.2/Litbang/2015 and 1494/UN.14.2/Litbang/2016). All participants provided written consents to participate in this study.
Funding

The study was supported by a research Grant from Warmadewa University to SM.

\section{Publisher's Note}

Springer Nature remains neutral with regard to jurisdictional claims in published maps and institutional affiliations.

Received: 4 December 2018 Accepted: 6 March 2019

Published online: 12 March 2019

\section{References}

1. Bhatt $\mathrm{S}$, Gething PW, Brady OJ, Messina JP, Farlow AW, Moyes $\mathrm{CL}$, et al. The global distribution and burden of dengue. Nature. 2013;496:504-7.

2. Henchal EA, Putnak JR. The dengue viruses. Clin Microbiol Rev. 1990:3:376-96.

3. Simmons CP, Farrar JJ, van Nguyen VC, Wills B. Dengue. N Engl J Med. 2012;366:1423-32.

4. Martina BEE, Koraka P, Osterhaus ADME. Dengue virus pathogenesis: an integrated view. Clin Microbiol Rev. 2009;22:564-81.

5. Guzman MG, Halstead SB, Artsob H, Buchy P, Farrar J, Gubler DJ, et al. Dengue: a continuing global threat. Nat Rev Microbiol. 2010;8(12 Suppl):S7-16.

6. Anders KL, Nguyet NM, Chau NVV, Hung NT, Thuy TT, Lien LB, et al. Epidemiological factors associated with dengue shock syndrome and mortality in hospitalized dengue patients in Ho Chi Minh City, Vietnam. Am J Trop Med Hyg. 2011;84:127-34.

7. Kliks SC, Nimmanitya S, Nisalak A, Burke DS. Evidence that maternal dengue antibodies are important in the development of dengue hemorrhagic fever in infants. Am J Trop Med Hyg. 1988;38:411-9.

8. WHO-SEARO. Comprehensive guidelines for prevention and control of dengue and dengue haemorrhagic fever. Revised and expanded. New Delhi, India: World Health Organization; 2011.

9. Lambrechts L, Scott TW, Gubler DJ. Consequences of the expanding global distribution of Aedes albopictus for dengue virus transmission. PLoS Negl Trop Dis. 2010;4:e646.

10. Balmaseda A, Hammond SN, Perez L, Tellez Y, Saborio SI, Mercado JC, et al. Serotype-specific differences in clinical manifestations of dengue. Am J Trop Med Hyg. 2006;74:449-56.

11. Dhanoa A, Hassan SS, Ngim CF, Lau CF, Chan TS, Adnan NAA, et al. Impact of dengue virus (DENV) co-infection on clinical manifestations, disease severity and laboratory parameters. BMC Infect Dis. 2016;16:406.

12. Lardo S, Utami Y, Yohan B, Tarigan SM, Santoso WD, Nainggolan L, et al. Concurrent infections of dengue viruses serotype 2 and 3 in patient with severe dengue from Jakarta, Indonesia. Asian Pac J Trop Med. 2016;9:134-40.

13. Hammon WM. Dengue hemorrhagic fever-do we know its cause? Am J Trop Med Hyg. 1973;22:82-91.

14. Gubler DJ, Kuno G, Sather GE, Waterman SH. A case of natural concurrent human infection with two dengue viruses. Am J Trop Med Hyg. 1985:34:170-3.

15. Loroño-Pino MA, Cropp CB, Farfán JA, Vorndam AV, Rodríguez-Angulo EM Rosado-Paredes EP, et al. Common occurrence of concurrent infections by multiple dengue virus serotypes. Am J Trop Med Hyg. 1999;61:725-30.

16. Megawati D, Masyeni S, Yohan B, Lestarini A, Hayati RF, Meutiawati F, et al. Dengue in Bali: clinical characteristics and genetic diversity of circulating dengue viruses. PLoS Negl Trop Dis. 2017;11:e0005483.

17. Masyeni S, Yohan B, Somia IKA, Myint KSA, Sasmono RT. Dengue infection in international travellers visiting Bali, Indonesia. J Travel Med. 2018;25:tay061.

18. Wardhani P, Aryati A, Yohan B, Trimarsanto H, Setianingsih TY, Puspitasari $D$, et al. Clinical and virological characteristics of dengue in Surabaya, Indonesia. PLoS ONE. 2017;12:e0178443.

19. Sasmono RT, Aryati A, Wardhani P, Yohan B, Trimarsanto H, Fahri S, et al. Performance of Simplexa dengue molecular assay compared to conventional and SYBR green RT-PCR for detection of dengue infection in Indonesia. PLoS ONE. 2014;9:e103815. 
20. Fahri S, Yohan B, Trimarsanto H, Sayono S, Hadisaputro S, Dharmana E, et al. Molecular surveillance of dengue in Semarang, Indonesia revealed the circulation of an old genotype of dengue virus serotype-1. PLoS Negl Trop Dis. 2013;7:e2354.

21. Twiddy SS, Farrar JJ, Vinh Chau N, Wills B, Gould EA, Gritsun T, et al. Phylogenetic relationships and differential selection pressures among genotypes of dengue-2 virus. Virology. 2002;298:63-72.

22. Lanciotti RS, Gubler DJ, Trent DW. Molecular evolution and phylogeny of dengue-4 viruses. J Gen Virol. 1997:78(Pt 9):2279-84.

23. Haryanto S, Hayati RF, Yohan B, Sijabat L, Sihite IF, Fahri S, et al. The molecular and clinical features of dengue during outbreak in Jambi, Indonesia in 2015. Pathog Glob Health. 2015;2016:1-11.

24. Sasmono RT, Wahid I, Trimarsanto H, Yohan B, Wahyuni S, Hertanto M, et al. Genomic analysis and growth characteristic of dengue viruses from Makassar, Indonesia. Infect Genet Evol. 2015;32:165-77.

25. Lee I-K, Liu J-W, Yang KD. Fatal dengue hemorrhagic fever in adults: emphasizing the evolutionary pre-fatal clinical and laboratory manifestations. PLoS Negl Trop Dis. 2012;6:e1532.

26. Rocco IM, Barbosa ML, Kanomata EH. Simultaneous infection with dengue 1 and 2 in a Brazilian patient. Rev Inst Med Trop Sao Paulo. 1998;40:151-4.
27. dos Santos CLS, Bastos MAA, Sallum MAM, Rocco IM. Molecular characterization of dengue viruses type 1 and 2 isolated from a concurrent human infection. Rev Inst Med Trop Sao Paulo. 2003;45:11-6.

28. de Figueiredo RMP, Naveca FG, Oliveira CM, de Bastos MS, Mourão MPG, de Viana SS, et al. Co-infection of Dengue virus by serotypes 3 and 4 in patients from Amazonas, Brazil. Rev Inst Med Trop Sao Paulo. 2011;53:321-3.

29. Yamanaka A, Mulyatno KC, Susilowati H, Hendrianto E, Ginting AP, Sary $\mathrm{DD}$, et al. Displacement of the predominant dengue virus from type 2 to type 1 with a subsequent genotype shift from IV to I in Surabaya, Indonesia 2008-2010. PLoS ONE. 2011;6:e27322.

30. Vaughn DW, Green S, Kalayanarooj S, Innis BL, Nimmannitya S, Suntayakorn $\mathrm{S}$, et al. Dengue viremia titer, antibody response pattern, and virus serotype correlate with disease severity. J Infect Dis. 2000;181:2-9.

31. Pozo-Aguilar JO, Monroy-Martínez V, Díaz D, Barrios-Palacios J, Ramos C, Ulloa-García A, et al. Evaluation of host and viral factors associated with severe dengue based on the, WHO classification. Parasit Vectors. 2009;2014:7. https://doi.org/10.1186/s13071-014-0590-7.
Ready to submit your research? Choose BMC and benefit from:

- fast, convenient online submission

- thorough peer review by experienced researchers in your field

- rapid publication on acceptance

- support for research data, including large and complex data types

- gold Open Access which fosters wider collaboration and increased citations

- maximum visibility for your research: over 100M website views per year

At BMC, research is always in progress.

Learn more biomedcentral.com/submissions 